\title{
Isotope and trace element studies of the Xingdi II mafic-ultramafic complex in the northern rim of the Tarim Craton: Evidence for emplacement in a Neoproterozoic subduction zone
}

\author{
Hongjin Chen ${ }^{\mathrm{a}}$, Yanjing Chen ${ }^{\mathrm{a}, *}$, Edward M. Ripley ${ }^{\mathrm{b}}$, Chusi Li ${ }^{\mathrm{b}}$, Xiaohua Deng ${ }^{\mathrm{c}}$, Suwei Yue ${ }^{\mathrm{d}}$, \\ Zhen Zheng ${ }^{\mathrm{a}}$, Bin $\mathrm{Fu}^{\mathrm{e}}$ \\ ${ }^{a}$ Key Laboratory of Orogen and Crustal Evolution, Peking University, Beijing 100871, China \\ b Department of Geological Sciences, Indiana University, Bloomington, IN 47405, USA \\ c Beijing Institute of Geology for Mineral Resources, Beijing 100012, China \\ d Guangzhou College, South China University of Technology, Guangzhou 510802, China \\ e Research School of Earth Sciences, The Australian National University, Canberra, ACT 0200, Australia
}

\section{A R T I C L E I N F O}

\section{Article history:}

Received 3 August 2016

Accepted 24 January 2017

Available online 03 February 2017

\section{Keywords:}

Mafic-ultramafic rocks

Mantle plume

Subduction

Tarim Craton

Rodinia

\begin{abstract}
A B S T R A C T
The Xingdi II mafic-ultramafic complex is located in the northern rim of the Tarim Craton, Northern Xinjiang, NW China. This complex is mainly composed of gabbro, gabbronorite, websterite and lherzolite, plus minor granodiorites and granites. The geodynamic setting of this complex and other Neoproterozoic mafic-ultramafic complexes in the region is debated, with opinions varying from mantle plume to a continental arc. A new zircon $\mathrm{U}-\mathrm{Pb}$ age from this study reveals > 7-myr difference for two gabbroic intrusive phases in the Xingdi II mafic-ultramafic complex and up to a 21-myr difference between this complex and the nearby mafic-ultramafic complexes that occur $<12 \mathrm{~km}$ from this complex. The age changes for the Neoproterozoic (730-820 Ma) mafic-ultramafic complexes in the area occur in different directions and hence a mantle plume origin for the complexes is unlikely. The Xingdi II mafic-ultramafic intrusive rocks are characterized by moderate light-REE enrichments and pronounced negative Nb anomaly, which are common for mafic-ultramafic rocks in convergent tectonic settings, and negative $\varepsilon N d(t)$ values $(-9.2$ to -5.1$)$ and elevated initial ${ }^{87} \mathrm{Sr} /{ }^{86} \mathrm{Sr}$ ratios (0.7061 to 0.7086), which indicate enriched source mantle plus crustal contamination. The $\varepsilon \mathrm{Hf}(\mathrm{t})$ values of zircon crystals from the Xingdi II mafic-ultramafic complex are between -2.8 and -7.0 . The trace element and isotope data together indicate that this complex formed from multiple pulses of contaminated subduction-related basaltic magma that were emplaced separately with a time gap of at least 7 myr. The results from this study support the viewpoint that in the Neoproterozoic the northern rim of the Tarim Craton was an active continental margin that belongs to the Circum-Rodinia Subduction System.
\end{abstract}

(c) 2017 Elsevier B.V. All rights reserved.

\section{Introduction}

The Tarim Craton is considered to have been a part of the Rodinia supercontinent during the Neoproterozoic based on the correlation of paleomagnetic poles, glacial diamictite-bearing sedimentary sequences and magmatic events within Australia and the South China Craton. The Quruqtagh block is located at the northeastern margin of the Tarim Craton, and is one of the major early Precambrian basement blocks of the Tarim Craton. The origin of Neoproterozoic igneous rocks in the Quruqtagh block has been subject to debate for a long time. Some researchers (Long et al., 2011a, 2011b; Shu et al., 2011; Xu et al., 2005; Zhang et al., 2007) suggest that they are related to two episodes of

\footnotetext{
* Corresponding author.

E-mail address: yjchen@pku.edu.cn (Y. Chen).
}

super plume activity during the breakup of the Rodinia supercontinent. Other researchers have argued that the Neoproterozoic igneous rocks were formed at arc-settings as a result of oceanic crust subduction along the northern margin of the Tarim Craton (Ge et al., 2014; Guo et al., 2005; Jiang et al., 2005; Li et al., 1998; Yuan et al., 2002).

When applying a mantle plume model, we should consider the fact that due to plate movement above a mantle plume or hotspot (Morgan, 1971), an age progression of magma emplaced in the crust should be apparent. Examples include the Hawaii and Yellowstone hotspots where Tilling et al. (2010) and Branney et al. (2008) have shown an 1000-km progression for every 10 myr. Such a hotspot track is extremely useful in evaluating any hypothetical mantle plume model proposed for an ancient protracted mafic-ultramafic intrusive belt or cluster in the crust.

In this communication, we report zircon SHRIMP U-Pb data, zircon $\mathrm{Hf}$ isotopes, whole rock major and trace elements and $\mathrm{Sr}-\mathrm{Nd}$ isotopes of the Xingdi II mafic-ultramafic complex in the Quruqtagh block. 
These data, along with data reported from the literature, are used to show that the Xingdi II mafic-ultramafic complex was emplaced in a subduction zone setting, and is not related to magmatism above a mantle plume.

\section{Geological setting}

The Tarim Craton, which is considered as one of the three major cratonic blocks in China (North China, Tarim and Yangtze), is located in northwestern China (Fig. 1). The Quruqtagh (or Kuluktage) block is located in the northeastern margin of the Tarim Craton, and is one of the major early Precambrian basement blocks that comprise the Tarim Craton (Fig. 2). The Quruqtagh block is composed of two major lithologic units referred to as the basement and the sedimentary cover. The basement rocks are composed of Neoarchean TTG (tonalite-trondhjemitegranodiorite) and granitic gneiss with amphibolites and paragneiss enclaves (2.65-2.51 Ga), early Paleoproterozoic orthogneiss (2.47-2.46 Ga and 2.36-2.29 Ga), late Paleoproterozoic granitoids (1.94-1.93 Ga) and supracrustal rocks (2.0-1.85 Ga) (Ge et al., 2014; Long et al., 2010; Shu et al., 2011). All of these rocks were metamorphosed to upper amphibolite or granulite facies at circa 1.9-1.8 Ga (Ge et al., 2014) and are overlain by Mesoproterozoic to early Neoproterozoic clastic and carbonate sedimentary rocks (Gao et al., 1993; Lu et al., 2008). Archean gneisses are exposed to the north of the Quruqtagh block; the oldest rocks are known as the Tuoge Complex where a zircon multi-grain TIMS U-Pb age of $2582 \pm 11$ Ma has been determined (Lu, 1992). Paleoproterozoic metamorphic rocks are widespread in the Quruqtagh block and are known as the Xingditage Group. This group comprises older metamorphic mafic and felsic intrusions and high-grade metamorphic supracrustal rocks. Neoproterozoic clastic and carbonate sedimentary rocks, which are known as the Paergangtagh Group and the Quruqtagh Group, are also present in the northern portion of the Quruqtagh block. A diverse set of Neoproterozoic magmatic rocks have been documented in the Quruqtagh block, including (1) voluminous granitoids, mostly emplaced between 830-735 Ma and 660-630 Ma, (2) circa $800 \mathrm{Ma}$ mafic-ultramafic-carbonatite complexes, (3) circa $760 \mathrm{Ma}$ and $735 \mathrm{Ma}$ bimodal intrusive complexes, and (4) mafic dyke swarms emplaced circa $820 \mathrm{Ma}$, 780-770 Ma and 660-630 Ma (Ge et al., 2014; Zhang et al., 2012; Zhu et al., 2011a, 2011b).

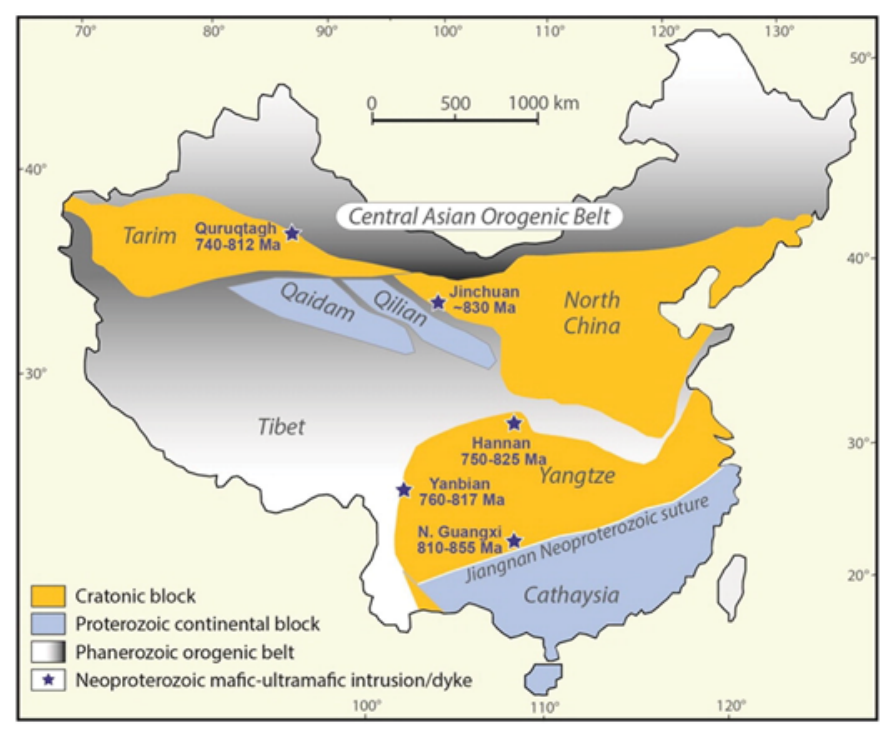

Fig. 1. Precambrian continental blocks in China, showing the locations of some Neoproterozoic mafic-ultramafic intrusive clusters. The base map is modified from Zhao and Cawood (2012). The zircon U-Pb ages for the mafic-ultramafic intrusive rocks are from Dong et al. (2012), Li et al. (2010), Li et al. (1999), Munteanu et al. (2010), Wang et al. (2006), Yao et al. (2014), Zhang et al. (2007, 2009, 2011, 2012), Zhang et al. (2010), and Zhu et al. (2008).
The mafic-ultramafic intrusions in the Xingdi region are distributed in an approximately $\mathrm{E}-\mathrm{W}$ direction along the southern margin of the Quruqtagh block. The four major mafic-ultramafic intrusions in this region are referred to as the Xingdi I, II, III and IV complexes in the literature. $\mathrm{Fe}-\mathrm{Cu}-\mathrm{Ni}$ sulfide mineralization is present in the Xingdi I, II and IV complexes but not in the Xingdi III complex. The granites that occur within the Xingdi I and II complexes yield zircon U-Pb ages of $743 \pm$ $2.5 \mathrm{Ma}$ (G1) and $739 \pm 2.5 \mathrm{Ma}$ (G2), respectively (Cao et al., 2014). Both occurrences show pronounced negative $\mathrm{Nb}-\mathrm{Ta}$ anomalies (Cao et al., 2014). The author interpreted the G1 granites, which have crustal $\mathrm{Sr}-\mathrm{Nd}$ isotope compositions, to be an alkaline A-type, and the G2 granites, which show mixing Sr-Nd isotope compositions between mantle and crustal materials, to be a high-K calc-alkaline I-type.

The Xingdi II mafic-ultramafic complex is a funnel-shaped intrusive complex, surrounded by the Xingditage Group Paleoproterozoic amphibolite facies metasedimentary rocks (XBGM, 1993). The complex is mainly composed of gabbro, gabbro norite, websterite and lherzolite (Fig. 2c). The contacts between different rock types are sharp but no chilled margins are observed. The gabbro (Fig. 3a) and gabbronorite (Fig. 3b, c) together make up about $50 \%$ of the outcrop area of the complex. They mainly occur in the middle and western areas. Lesser amounts are found in the southeastern area and along the northern margin of the complex. This phase mainly includes gabbro, olivine gabbro, gabbronorite and olivine gabbronorite. They are of medium to coarse grain texture, massive structure; and contain varying percentages of clinopyroxene (30-35\%), orthopyroxene (10-40\%), plagioclase (25-60\%), minor olivine, hornblende and biotite. The clinopyroxene and orthopyroxene are mostly euhedral, while the plagioclase is mainly anhedral and surrounds clinopyroxene and orthopyroxene.

The websterite (Fig. 3d, e) accounts for about 35\% of the outcrop area and mainly occurs in the northeastern portion of the complex. This phase mainly includes websterite, olivine websterite, minor clinopyroxenite and orthopyroxenite. They are of medium to coarse grain texture, massive structure; and contain varying percentages of clinopyroxene (10-40\%), orthopyroxene (10-40\%), minor olivine, plagioclase, hornblende and biotite. The olivine is mostly euhedral, while the clinopyroxene and orthopyroxene are mainly anhedral and surround olivine.

Lherzolite (Fig. 3f) accounts for 15\% of the outcrop area of the complex and mainly occurs in the eastern portions of the complex. Minor harzburgite, wehrlite and hornblende lherzolite are associated with the lherzolite. Lherzolites are of medium to coarse grain texture, massive structure with variable amounts of olivine (40-70\%), clinopyroxene (5-25\%), orthopyroxene (5-20\%), sulfide minerals (5-15\%) and minor plagioclase. The olivine is mostly euhedral to semi-euhedral, while the clinopyroxene and orthopyroxene and sulfide minerals are mainly anhedral and surround olivine.

\section{Analytical methods}

All the samples used in this study were collected from outcrops. Pretreatment of samples was carried out at the Key Laboratory of Orogen and Crustal Evolution, Ministry of Education, School of Earth and Space Sciences, Peking University. Whole-rock samples were trimmed to remove weathered surface, and then chipped and powdered in an agate mill to about 200 mesh before analyzing for major and trace elements and $\mathrm{Sr}-\mathrm{Nd}$ isotopes.

The sample for zircon selection was chipped to 60-80 mesh. Zircon was separated by conventional heavy liquids and magnetic techniques, and then hand-picked under a binocular microscope. Cathode luminescence (CL) images of the selected zircon crystals were acquired by a $\mathrm{MonoCL}_{3}+$ (Gatan Company, England) cathode luminescence spectroscope attached to a Quanta 400 FEG scanning electron microscope at the State Key Laboratory of Continental Dynamics in Northwest University, Xi'an. The CL images were used for selecting target sites for $\mathrm{U}-\mathrm{Th}-\mathrm{Pb}$, and $\mathrm{Lu}-\mathrm{Hf}$ isotope analyses. 


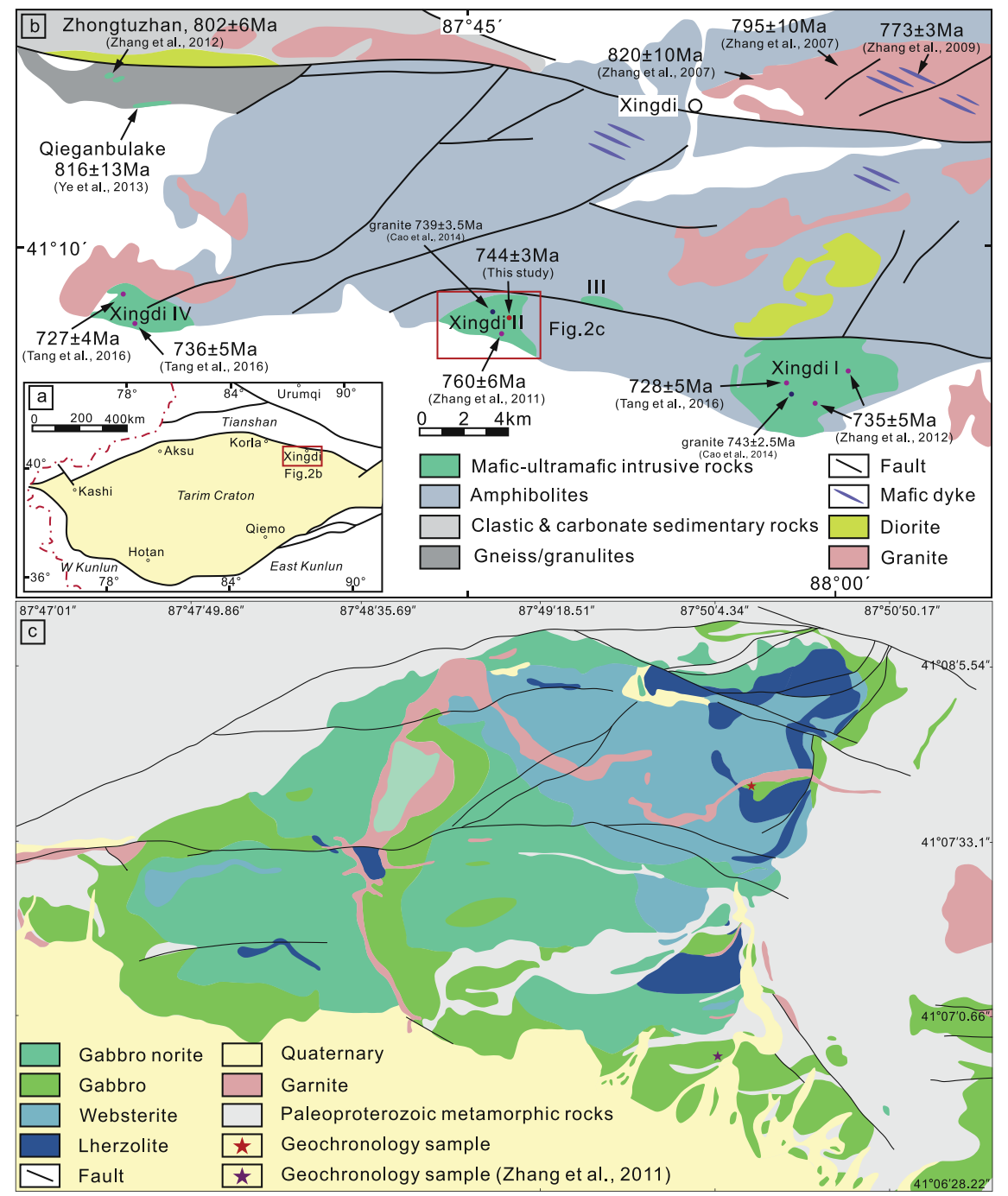

Fig. 2. (a): Simplified geological map of the Tarim Craton. (b): Simplified geological map of the Quruqtagh block, showing distribution of Neoproterozoic igneous rocks (modified from Zhang et al., 2012). (c): Simplified geological map of the Xingdi II mafic-ultramafic complex (modified from XBGMR-3, 2003).

In situ U-Th-Pb analysis of zircon was performed using a sensitive, high-resolution ion microprobe (SHRIMP-II) at the Research School of Earth Sciences, Australian National University. Instrumental conditions and data acquisition were as described by Compston et al. (1992). Age calculations were done using the software Isoplot/Ex (Ludwig, 2003). Isotopic ratios and single ages are reported with $1 \sigma$ errors. The concordia age was calculated with $2 \sigma$ errors.

The Lu-Hf isotopes of the dated zircon crystals were determined using a Nu Plasma HR MC-ICP-MS instrument (Nu Instruments Ltd. UK) at the State Key Laboratory of Continental Dynamics in Northwest University, Xi'an. The detailed analytical procedures were as described in Yuan et al. (2008). The 91500 and GJ-1 zircon standards were used for calibration and quality control. Interference of ${ }^{176} \mathrm{Lu}$ on ${ }^{176} \mathrm{Hf}$ was corrected by measuring the intensity of the interference-free ${ }^{175} \mathrm{Lu}$, using the recommended ${ }^{176} \mathrm{Lu} /{ }^{175} \mathrm{Lu}$ ratio of 0.02669 (DeBievre and Taylor, 1993). The interference of ${ }^{176} \mathrm{Yb}$ on ${ }^{176} \mathrm{Hf}$ was corrected using a recommended ${ }^{176} \mathrm{Yb} /{ }^{172} \mathrm{Yb}$ ratio of 0.5586 (Chu et al., 2002). During analysis, the obtained ${ }^{176} \mathrm{Hf} /{ }^{177} \mathrm{Hf}$ ratios were $0.282296 \pm 50(2 \sigma)$ for 91500 and $0.282019 \pm 15(2 \sigma)$ for $\mathrm{GJ}-1$, which are in good agreement with the recommended ratios of $0.2823075 \pm 58(2 \sigma)$ for the 91500 zircon standard and $0.282015 \pm 19(2 \sigma)$ for the GJ-1 zircon standard (Elhlou et al. 2006). The ${ }^{176} \mathrm{Yb} /{ }^{177} \mathrm{Hf},{ }^{176} \mathrm{Lu} /{ }^{177} \mathrm{Hf}$ and ${ }^{176} \mathrm{Hf} /{ }^{177} \mathrm{Hf}$ ratios are reported with $1 \sigma$ errors. The initial ${ }^{176} \mathrm{Hf} /{ }^{177} \mathrm{Hf}$ ratio and $\varepsilon \mathrm{Hf}(\mathrm{t})$ were calculated referring to chondrite at the time of zircon crystallization from magma. The decay constant of $1.867 \times 10^{-11}$ year $^{-1}$ for ${ }^{176} \mathrm{Lu}$ (Söderlund et al., 2004) and the chondritic ratios of ${ }^{176} \mathrm{Hf} /{ }^{177} \mathrm{Hf}(0.282772)$ and ${ }^{176} \mathrm{Lu} /{ }^{177} \mathrm{Hf}$ (0.0332) from Blichert-Toft and Albarède (1997) were used for the calculations.

Mineral compositions were determined by wavelength dispersive X-ray analysis using a CAMECA SX50 electron microprobe at Indiana University. The analytical conditions for major and minor elements were $15 \mathrm{kV}, 20 \mathrm{nA}$ beam current, $1 \mu$ beam size, and peak-counting time of $20 \mathrm{~s}$. Nickel and Ca in olivine were analyzed using a beam current of $100 \mathrm{nA}$ and a peak-counting time of $50 \mathrm{~s}$. The detection limits for $\mathrm{Ni}$ and $\mathrm{Ca}$ under such conditions are $100 \mathrm{ppm}$ and $50 \mathrm{ppm}$.

The major elements were determined by X-ray Fluorescence (XRF, Thermo ArlAdvant $\mathrm{XP}+$ ) on fused glass disks. $0.5 \mathrm{~g}$ sample powders (200 mesh) were fused with $3.6 \mathrm{~g} \mathrm{Li}_{2} \mathrm{~B}_{4} \mathrm{O}_{7}$ and 3-4 drops of $\mathrm{NH}_{4} \mathrm{Br}$ in a platinum crucible at a temperature of $1050{ }^{\circ} \mathrm{C}$ for 10 min to make glass beads. Analytical precision was generally within $2-3 \%$. Trace elements were determined using a Finnigan Element ICP-MS on solutions. $40 \mathrm{~g}$ sample powders were placed into the Teflon containers with HF and $\mathrm{HNO}_{3}$, and then fused at a temperature of $200{ }^{\circ} \mathrm{C}$ for 5 days.

Powders for $\mathrm{Sr}-\mathrm{Nd}$ isotope analyses were dissolved by acid digestion $\left(\mathrm{HNO}_{3}+\mathrm{HF}\right)$ in a sealed Savillex beaker on a hot plate $\left(80^{\circ} \mathrm{C}\right)$. Separation of $\mathrm{Sm}$ and $\mathrm{Nd}$ was done using a routine two-column ion-exchange technique. Isotope ratios were measured using a TRITON Thermal Ionization Spectrometer (TIMS) in the Tianjin Center of China Geological 


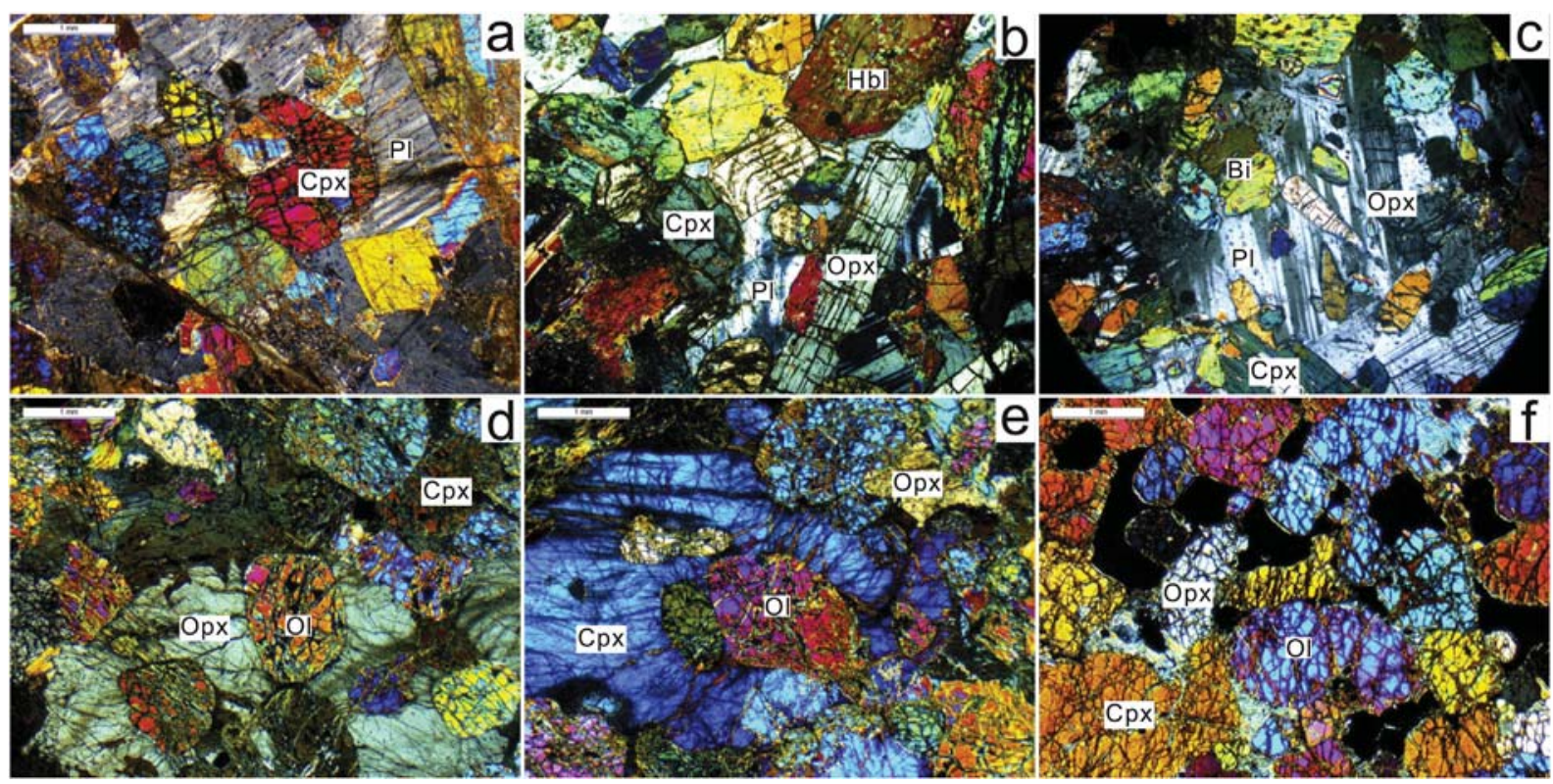

Fig. 3. Photomicrographs of gabbro (a), gabbro norite (b, c), websterite (d, e) and lherzolite (f) from Xingdi II mafic-ultramafic complex. Mineral abbreviations are as follows: Ol = olivine, $\mathrm{Cpx}=$ clinopyroxene, $\mathrm{Opx}=$ orthopyroxene, $\mathrm{Pl}=$ plagioclase, $\mathrm{Hbl}=$ hornblende, $\mathrm{Bi}=$ biotite.

Survey. The NBS-987 Sr standard and the Jndi Nd standard analyzed together with our samples gave a mean ${ }^{87} \mathrm{Sr} /{ }^{86} \mathrm{Sr}$ value of $0.710231 \pm$ $0.000012(2 \sigma)$ (the certified value is $0.710250 \pm 0.00002$; Li et al., 2012 ) and a mean ${ }^{143} \mathrm{Nd} /{ }^{144} \mathrm{Nd}$ value of $0.512111 \pm 0.000004(2 \sigma)$ (the certified value is $0.512115 \pm 0.000007$; Tanaka et al., 2000), respectively. The BCR-2 standard analyzed together with the samples gave a mean ${ }^{87} \mathrm{Sr} /{ }^{86} \mathrm{Sr}$ value of $0.704966 \pm 0.000003(2 \sigma)$ (the certified value is 0.704958; Raczek et al., 2003) and a mean ${ }^{143} \mathrm{Nd} /{ }^{144} \mathrm{Nd}$ value of $0.512461 \pm 0.000003(2 \sigma)$ (the certified value is 0.512643 ; Raczek et al., 2003), respectively.

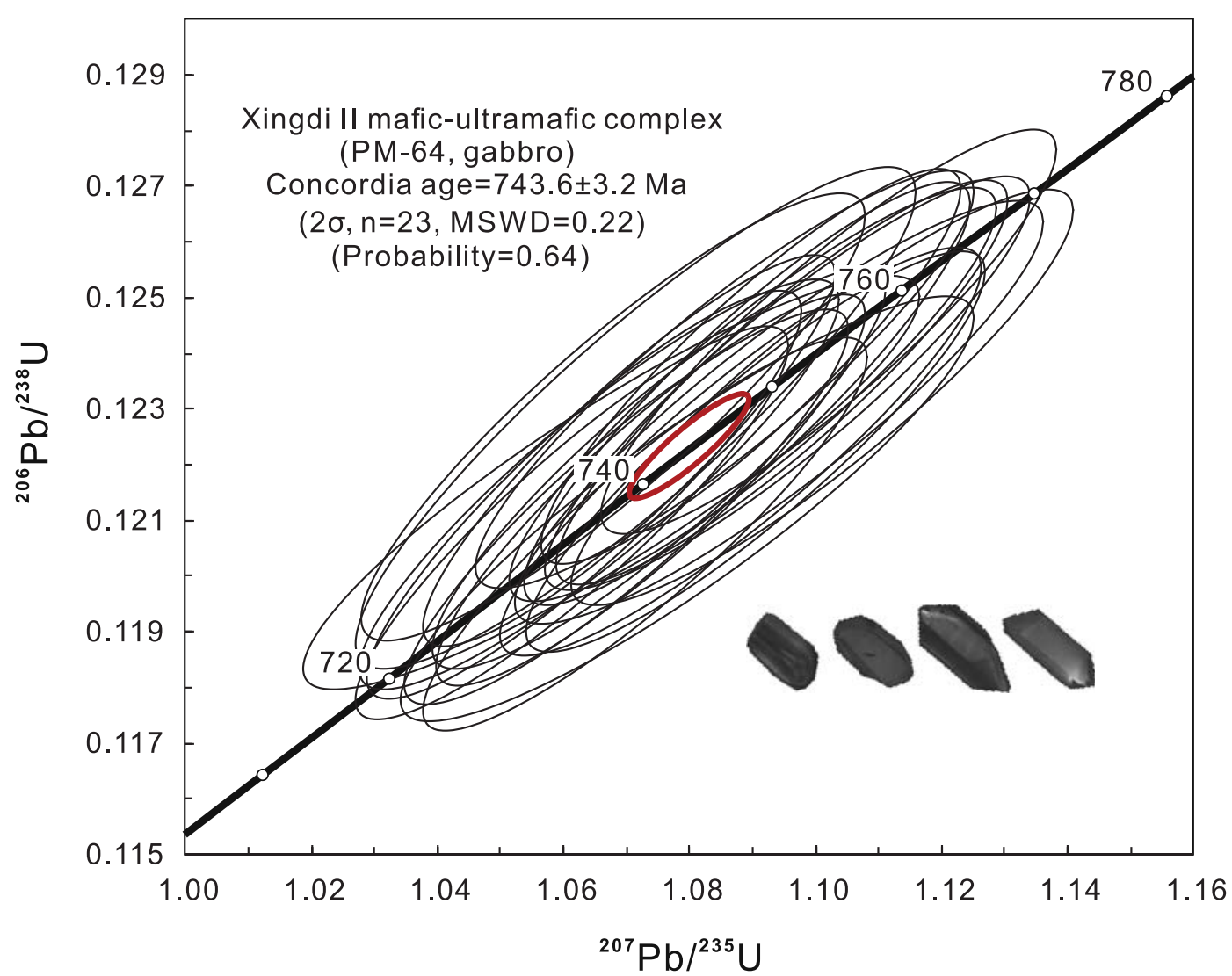

Fig. 4. Concordia $\mathrm{U}-\mathrm{Pb}$ isotope age diagram of magmatic zircon crystals from the Xingdi II mafic-ultramafic complex. 


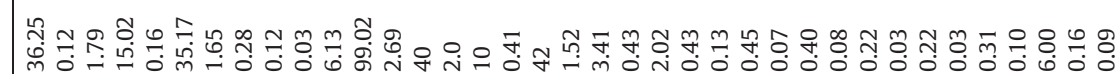

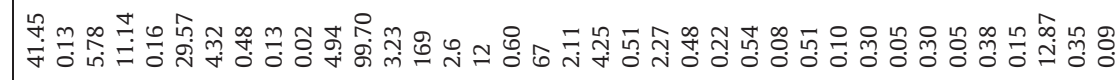

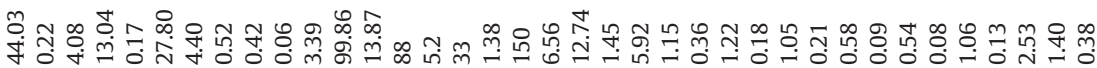

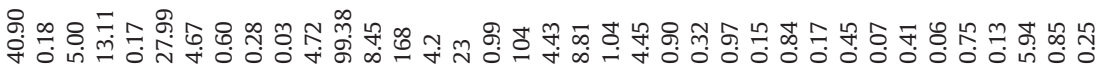

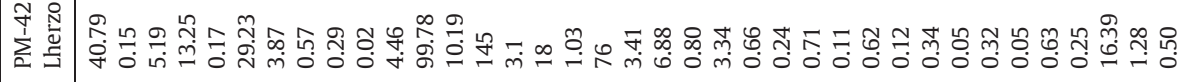

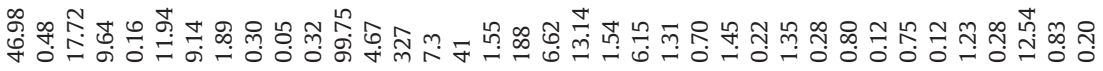

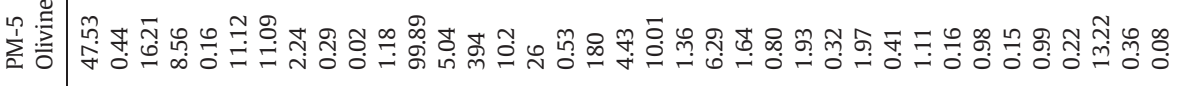

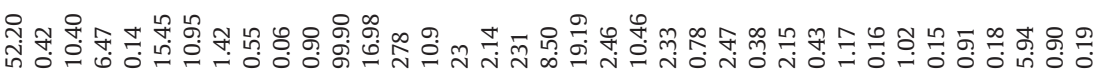

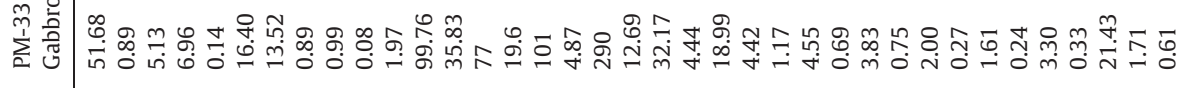

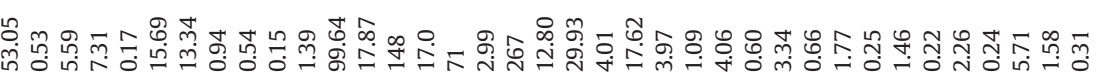

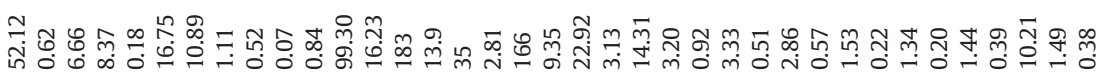

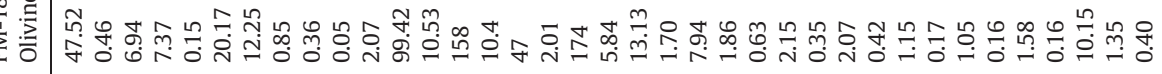

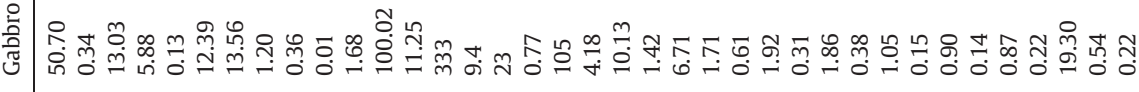

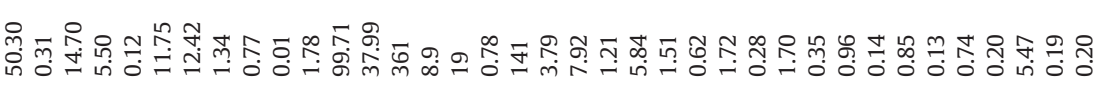



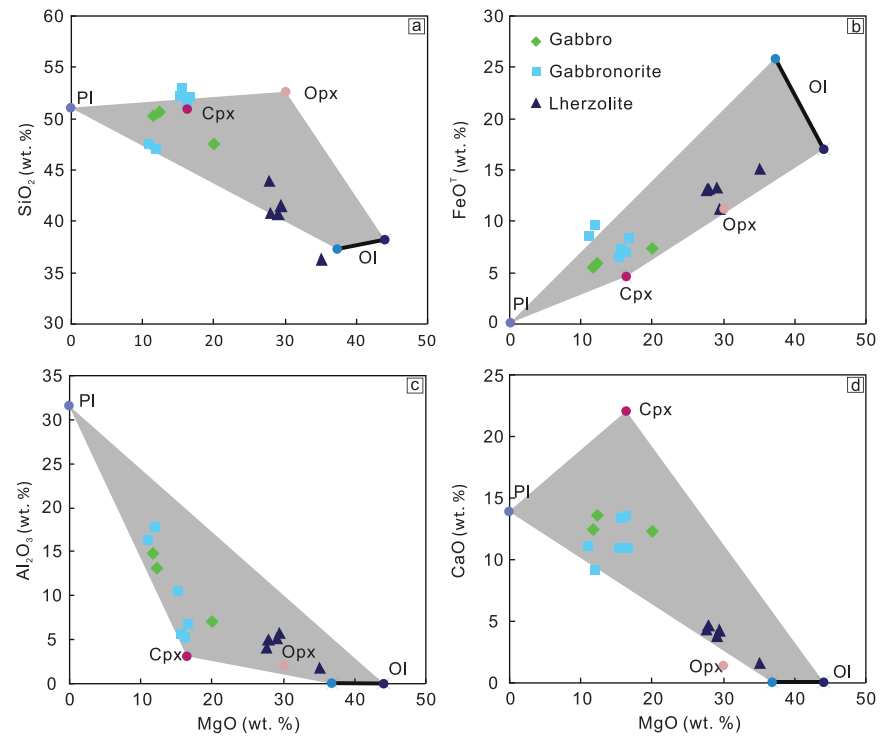

Fig. 5. Compositional comparison of whole rocks with major rock-forming minerals from the Xingdi II mafic-ultramafic complex.

\section{Results}

\subsection{Zircon U-Pb geochronology and Lu-Hf isotopes}

The U-Pb isotopic data of selected zircon grains from a gabbro sample (PM-64) are listed in Table S1 and illustrated in Fig. 4. Most zircon crystals separated from this sample are transparent and colorless, with lengths ranging from 100 to $200 \mu$ and aspect ratios from 1:1 to 3:1. The CL images reveal that most zircon crystals have oscillatory zoning. Twenty-three analyses that focused on oscillatory-zoned rims of zircon grains yield a concordia $\mathrm{U}-\mathrm{Pb}$ age of $743.6 \pm 3.2 \mathrm{Ma}(\mathrm{MSWD}=0.22)$ (Fig. 4). Eighteen spot analyses for Lu-Hf isotopes were carried out on eighteen dated zircon grains. The calculated $\varepsilon \mathrm{Hf}(\mathrm{t})$ ranges from -2.8 to -7.0 (Table S2).

\subsection{Mineral chemistry}

The compositions of important minerals in the Xingdi II maficultramafic intrusive rocks are provided as supplementary materials (Table S3).

\subsection{Major and trace elements}

The concentrations of major and trace elements in the samples from the Xingdi II mafic-ultramafic complex are listed in Table 1. The major and trace element analyses of international reference materials and replicate analyses of our own samples are listed in Table S4. A comparison of whole-rock compositions and major rock-forming mineral compositions is illustrated in Fig. 5. In the comparison, the whole rock compositions are normalized to $100 \%$ on a LOI-free basis ( $\mathrm{LOI}=$ loss on ignition). The data indicate that the major element compositions of the Xingdi II gabbroic and ultramafic intrusive rocks are mainly controlled by the ratios of plagioclase to clinopyroxene and orthopyroxene, and olivine to clinopyroxene and orthopyroxene, respectively.

The mantle-normalized incompatible and immobile trace element patterns of the Xingdi I, II, and IV mafic-ultramafic intrusive rocks, the Quruqtagh mafic dyke and Qieganbulake complex are shown in Fig. 6. Large variations of incompatible trace element abundances mainly reflect highly variable amounts of inter-cumulus liquids in these rocks. The data shows that these rocks are characterized by moderate lightREE enrichments and pronounced negative $\mathrm{Nb}$ anomaly, which are similar to the pattern of average continental arc basalt but different from that of the average ocean island basalt which does not show a negative $\mathrm{Nb}$ anomaly.

\subsection{Sr-Nd isotopes}

Whole rock Sr-Nd isotopic compositions of the Xingdi II maficultramafic complex are listed in Table 2. The calculated \&Nd (744 Ma) and initial ${ }^{87} \mathrm{Sr} /{ }^{86} \mathrm{Sr}$ values range from -9.2 to -5.1 and from 0.7061 to 0.7086 , respectively. A comparison of our data and previous data (Zhang et al., 2011) for the sample complex is illustrated in Fig. 7. The ranges of the calculated initial ${ }^{87} \mathrm{Sr} /{ }^{86} \mathrm{Sr}$ values from these two different studies are similar. However, the calculated $\varepsilon N d(744 \mathrm{Ma})$ values for our

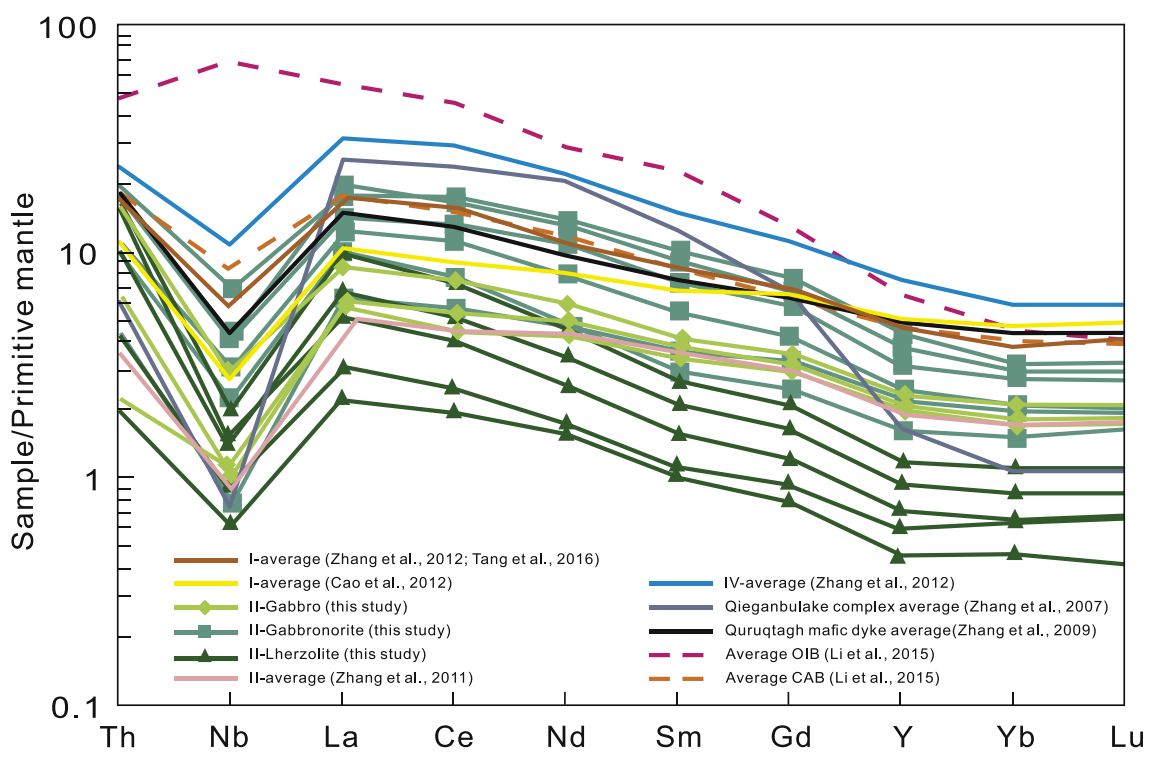

Fig. 6. Primitive mantle-normalized incompatible trace element patterns for the Xingdi II mafic-ultramafic complex. The average compositions of oceanic island basalts (OIB) and continental arc basalts (CAB) are from Li et al. (2015). The primitive mantle values for normalization are from Sun and McDonough (1989). 
Table 2

Sr-Nd isotopes of the Xingdi II mafic-ultramafic complex.

\begin{tabular}{|c|c|c|c|c|c|c|c|c|c|c|c|c|}
\hline Sample & Rock types & $\mathrm{T}(\mathrm{Ma})$ & $\mathrm{Rb}(\mu \mathrm{g} / \mathrm{g})$ & $\operatorname{Sr}(\mu \mathrm{g} / \mathrm{g})$ & ${ }^{87} \mathrm{Rb} /{ }^{86} \mathrm{Sr}$ & ${ }^{87} \mathrm{Sr} /{ }^{86} \mathrm{Sr}$ & $\left({ }^{87} \mathrm{Sr} /{ }^{86} \mathrm{Sr}\right) \mathrm{i}$ & $\mathrm{Nd}(\mu \mathrm{g} / \mathrm{g})$ & $\mathrm{Sm}(\mu \mathrm{g} / \mathrm{g})$ & ${ }^{147} \mathrm{Sm} /{ }^{144} \mathrm{Nd}$ & ${ }^{143} \mathrm{Nd} /{ }^{144} \mathrm{Nd}$ & $\varepsilon N d(t)$ \\
\hline XDX-3 & Gabbro & 744 & 37.99 & 361.36 & 0.3038 & 0.7104 & 0.7071 & 5.84 & 1.51 & 0.1563 & 0.5121 & -7.0 \\
\hline PM-72 & Gabbro & 744 & 11.25 & 333.47 & 0.0975 & 0.7089 & 0.7079 & 6.71 & 1.71 & 0.1541 & 0.5121 & -6.8 \\
\hline PM-18 & Olivine gabbro & 744 & 10.53 & 158.13 & 0.1924 & 0.7084 & 0.7064 & 7.94 & 1.86 & 0.1416 & 0.5121 & -5.1 \\
\hline PM-32 & Gabbronorite & 744 & 17.87 & 147.76 & 0.3496 & 0.7122 & 0.7085 & 17.62 & 3.97 & 0.1362 & 0.5119 & -9.1 \\
\hline PM-39 & Gabbronorite & 744 & 16.98 & 278.42 & 0.1762 & 0.7104 & 0.7086 & 10.46 & 2.33 & 0.1347 & 0.5119 & -8.6 \\
\hline PM-11 & Olivine gabbronorite & 744 & 4.67 & 327.06 & 0.0412 & 0.7072 & 0.7068 & 6.15 & 1.31 & 0.1288 & 0.5119 & -7.7 \\
\hline PM-42 & Lherzolite & 744 & 10.19 & 145.42 & 0.2025 & 0.7090 & 0.7068 & 3.34 & 0.66 & 0.1195 & 0.5119 & -7.0 \\
\hline PM-43 & Lherzolite & 744 & 8.45 & 168.26 & 0.1451 & 0.7093 & 0.7078 & 4.45 & 0.90 & 0.1223 & 0.5119 & -7.0 \\
\hline PM-44 & Lherzolite & 744 & 13.87 & 87.93 & 0.4559 & 0.7110 & 0.7061 & 5.92 & 1.15 & 0.1174 & 0.5119 & -7.6 \\
\hline PM-77 & Lherzolite & 744 & 2.69 & 39.91 & 0.1948 & 0.7107 & 0.7086 & 2.02 & 0.43 & 0.1287 & 0.5120 & -6.8 \\
\hline
\end{tabular}

samples are slightly lower, mainly due to the different intrusive phases that were sampled by the different research groups.

\section{Discussion}

\subsection{Source characteristics and crustal contamination}

As shown in Fig. 7, the inferred variations of the source mantle compositions for the Neoproterozoic mafic-ultramafic intrusive rocks in the Quruqtagh block range from isotopically undepleted to highly enriched (Fig. 7). Based on different ages, the mafic-ultramafic rocks in the Xingdi I and II complexes can be divided into two groups with contrasting $\mathrm{Sr}-\mathrm{Nd}$ isotope compositions (Fig. 7). One group plots close to the mixing line between a relatively primitive mantle-derived melt and the upper crust whereas the other group plots close to the mixing line between an enriched mantle-derived melt and the upper crust. This indicates the involvement of different mantle domains in the formation of a single complex at different stages. The granites in the Xingdi I complex have $\mathrm{Sr}-\mathrm{Nd}$ isotope compositions similar to those of the associated gabbroic rocks, indicating a common source. In contrast, the $\mathrm{Sr}-\mathrm{Nd}$ isotope compositions of the granites in the Xingdi II complex are significantly different from those of the associated gabbroic rocks, indicating different sources.

The negative correlation between initial ${ }^{87} \mathrm{Sr} /{ }^{86} \mathrm{Sr}$ ratios and $\varepsilon N d(t)$ values for the Xingdi II mafic-ultramafic complex can be explained by variable degrees of crustal contamination up to $16 \mathrm{wt} . \%$
(Fig. 7). Based on the upper limit of crustal contamination constrained by whole rock $\mathrm{Sr}-\mathrm{Nd}$ isotopes, the $\mathrm{eHf}(\mathrm{t})$ value for the parental magma of the magmatic zircon crystals from the Xingdi II mafic-ultramafic complex is estimated to be close to one, significantly lower than the value $(\sim 12)$ for magma derived from a depleted mantle in the Neoproterozoic (Fig. 8).

Immobile incompatible element ratios such as $\mathrm{Th} / \mathrm{Nb}$ are generally insensitive to secondary alteration, fractional crystallization and degrees of partial melting in the source region. Thus, these ratios can be used to evaluate source characteristics and crustal contamination. For example, a negative $\mathrm{Nb}$ anomaly (i.e., mantle normalized $\mathrm{Th} / \mathrm{Nb}>1$ ) could result from crustal assimilation or flux melting in a subduction zone. These two different processes can be distinguished using the combination of $\mathrm{Sr}-\mathrm{Nd}$ isotopes and trace element ratios. As shown in Fig. 9, the Neoproterozoic mafic-ultramafic complexes in the Quruqtagh block show no correlation between $\mathrm{Th} / \mathrm{Nb}$ ratios and $\varepsilon \mathrm{Nd}(\mathrm{t})$ values but a poor negative correlation between $\mathrm{Th} / \mathrm{Nb}$ ratios and initial ${ }^{87} \mathrm{Sr} /{ }^{86} \mathrm{Sr}$ ratios. These features suggest that the pronounced negative $\mathrm{Nb}$ anomaly in these rocks is not entirely due to crustal contamination but is also a primary feature of the magma. Since a negative $\mathrm{Nb}$ anomaly is most common in terrestrial arc basalts, we suggest that the parental magmas of the Neoproterozoic mafic-ultramafic rocks in the Quruqtagh block belong to arc basalts, and are not the partial melts of a mantle plume. This interpretation is also supported by the combination of $(\mathrm{Th} / \mathrm{Yb})_{\mathrm{N}}$ and $(\mathrm{Th} / \mathrm{Nb})_{\mathrm{N}}$ (Fig. 9c). As shown in this diagram, the Xingdi II maficultramafic rocks all plot far away from the mixing line between an
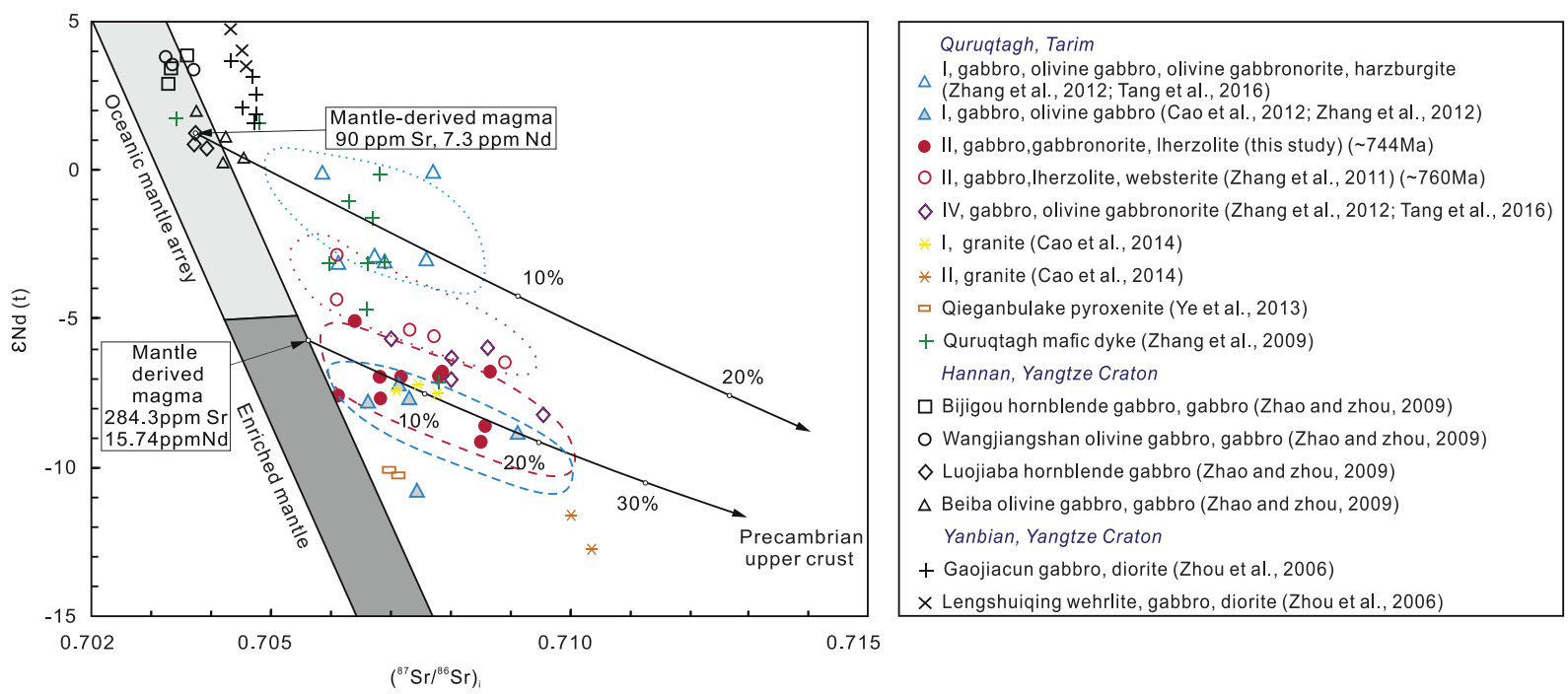

Fig. 7. Plot of whole rock $\varepsilon N d(t)$ versus $\left({ }^{87} \mathrm{Sr} /{ }^{86} \mathrm{Sr}\right)$ i for the Neoproterozoic mafic-ultramafic rocks and granites in the Quruqtagh block, Tarim Craton, and the Hannan and Yanbian regions, Yangtze Craton. The mantle Sr-Nd array is from Zindler and Hart (1986). Values used in mixing calculations: Precambrian upper crust, 27 ppm Nd, 320 ppm Sr (Rudnick and Gao, 2014 ), $\varepsilon N d(t)=-17,\left({ }^{87} \mathrm{Sr} /{ }^{86} \mathrm{Sr}\right) \mathrm{i}=0.7223$ (this study); enriched mantle derived magma, $16 \mathrm{ppm} \mathrm{Nd}, 284 \mathrm{ppm} \mathrm{Sr}\left(\mathrm{Li}\right.$ et al., 2015), $\varepsilon \mathrm{Nd}(\mathrm{t})=-5.7,\left({ }^{87} \mathrm{Sr} /{ }^{86} \mathrm{Sr}\right) \mathrm{i}=0.7056$; depleted mantle derived magma, $7.3 \mathrm{ppm} \mathrm{Nd}, 90 \mathrm{ppm} \mathrm{Sr}$ (Sun and McDonough, 1989), $\varepsilon \mathrm{Nd}(\mathrm{t})=3.55,\left({ }^{87} \mathrm{Sr} /{ }^{86} \mathrm{Sr}\right) \mathrm{i}=0.7034$. Reference data of Quruqtagh complex (Tarim) are cited from Zhang et al. (2009, 2011, 2012), Cao et al. (2012), Ye et al. (2013) and Tang et al. (2016), of Hannan (Yangtze) from Zhao and Zhou (2009), and of Yanbian (Yangtze) from Zhou et al. (2006). 


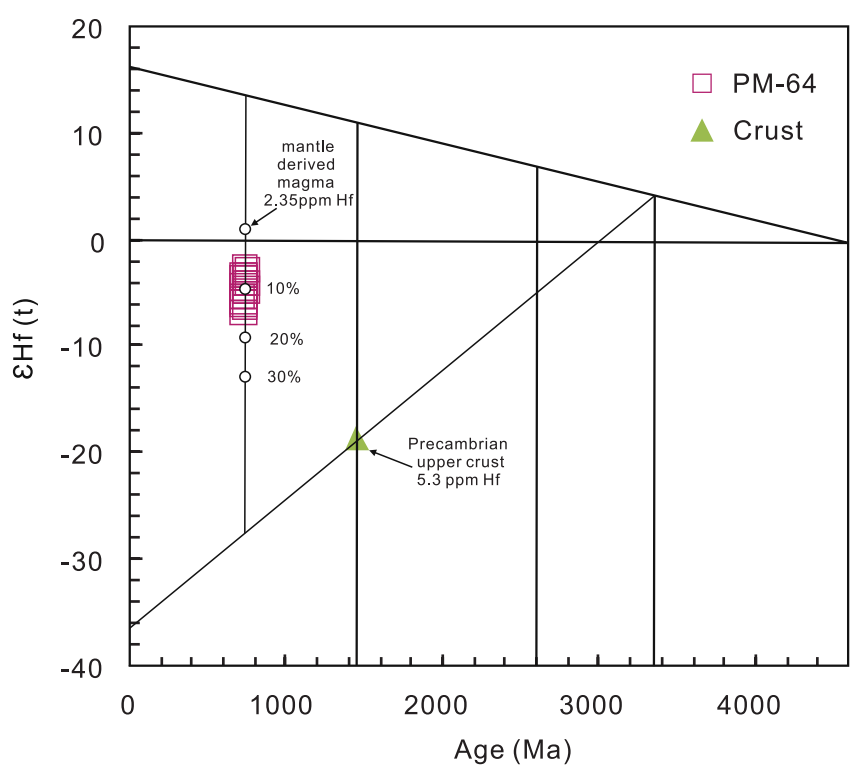

Fig. 8. Plot of $\varepsilon \mathrm{Hf}(\mathrm{t})$ versus ${ }^{206} \mathrm{~Pb} /{ }^{238} \mathrm{U}$ age of zircon crystals from the Xingdi II maficultramafic complex. Values used in mixing calculations: Precambrian upper crust, 5.3 ppm Hf (Rudnick and Gao, 2014), $\varepsilon \mathrm{Hf}(\mathrm{t})=-27.5$; mantle derived magma, $2.4 \mathrm{ppm}$ Hf (Li et al., 2015), $\varepsilon \mathrm{Hf}(\mathrm{t})=1.1$

OIB-like melt and the crust-derived granites that occur within the Xingdi II complex and are coeval with the gabbroic rocks of this complex, but close to the mixing line between the average values of the terrestrial arc basalts and the coeval granites. Clearly, the trace element data for the Neoproterozoic mafic-ultramafic intrusive rocks indicate that the parental magmas of these rocks formed by mixing between arc basalt and a crustal melt.

\subsection{Tectonic significance}

The most popular geodynamic model for the Neoproterozoic basaltic magmatism in the Quruqtagh block is that the intrusions were produced during two episodes of mantle plume activity at circa 825-800 Ma and 780-740 Ma (e.g., Xu et al., 2005; Zhang et al., 2012), which was first proposed by Li et al. (1999) for coeval events in South China. However, as shown in Fig. 10, although to a large degree the Neoproterozoic Quruqtagh mafic-ultramafic rocks temporally overlap with those in the western rim of the Yangtze Craton, they can be distinguished by different $\varepsilon \mathrm{Nd}(\mathrm{t})$ values. It is difficult to reconcile these differences by employing the same mantle plume that was thought to break up the Tarim Craton from the Yangtze Craton. The calculated $\varepsilon N d(t)$ values indicate that the source mantle for the Neoproterozoic mafic-ultramafic rocks in the Quruqtagh district is generally more enriched than that for the contemporaneous mafic-ultramafic intrusive clusters (Hannan, Yanbian) in the western margin of the Yangtze Craton (Figs. 7; 10).

The temporal-spatial distribution of the Neoproterozoic maficultramafic intrusions and mafic dykes in the Quruqtagh block of the Tarim Craton does not show a hotspot track that is expected for mantle plume-related magmatism such as the Hawaii and Yellowstone volcanic trains (Branney et al., 2008; Tilling et al., 2010). As shown in Fig. 2a, the age range for different gabbroic intrusive phases in the Xingdi II maficultramafic complex is at least 7-myr, which is almost twice the average analytical error. The age data from previous studies show that more significant age differences are present between different gabbroic intrusive phases in the other Neoproterozoic mafic-ultramafic complexes in the area (Fig. 2a). Moreover, there is a large age variation between the known Neoproterozoic mafic-ultramafic complexes in the area and

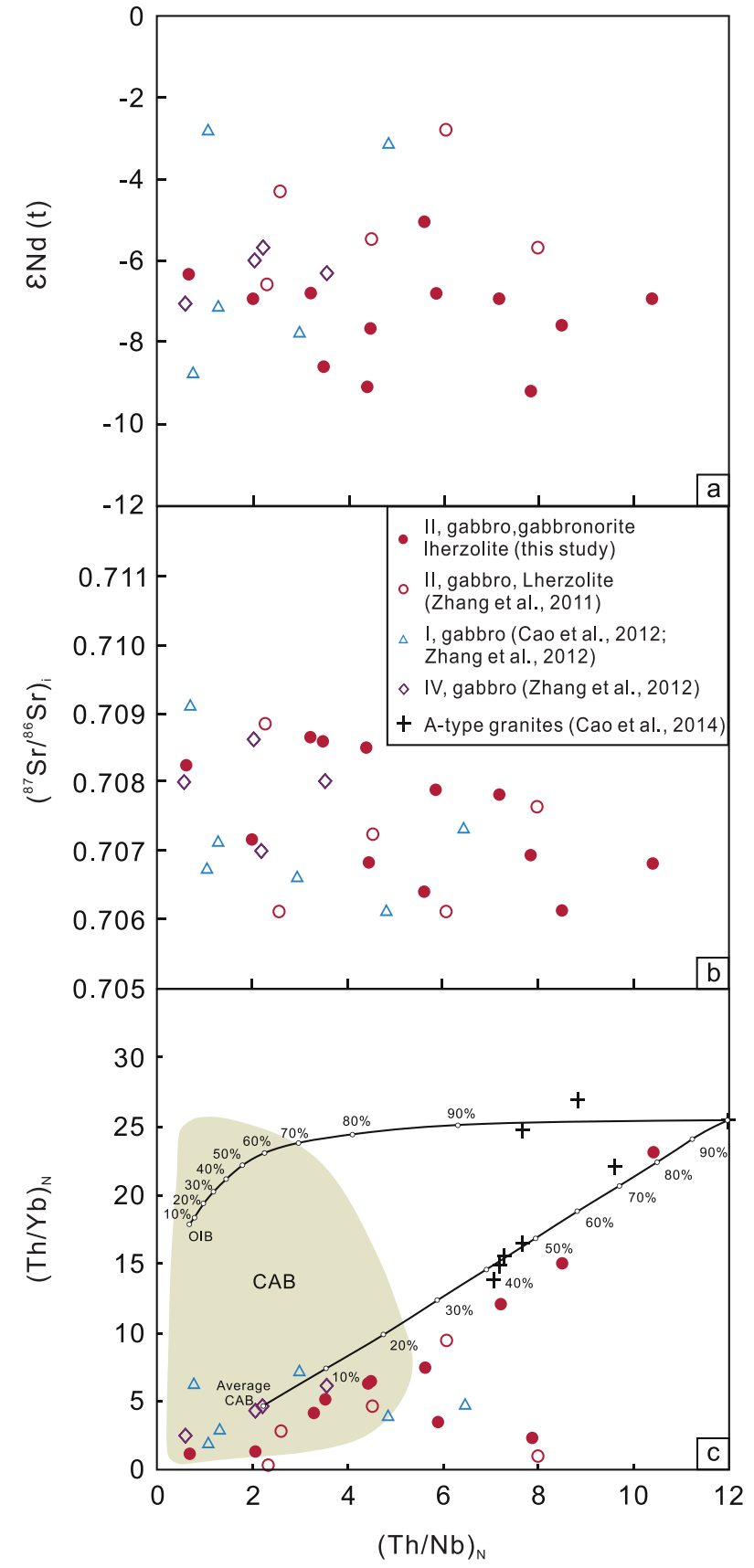

Fig. 9. (a): Plot of whole rock $(\mathrm{Th} / \mathrm{Nb})_{\mathrm{N}}$ versus $\varepsilon N d(t)$ for the Neoproterozoic maficultramafic rocks in the Quruqtagh block, Tarim Craton; (b): Plot of whole rock (Th/Nb) versus $\left({ }^{87} \mathrm{Sr} /{ }^{86} \mathrm{Sr}\right)$ i for the Neoproterozoic mafic-ultramafic rocks in the Quruqtagh block, Tarim Craton; (c): Plot of whole rock $(\mathrm{Th} / \mathrm{Nb})_{\mathrm{N}}$ versus $(\mathrm{Th} / \mathrm{Yb})_{\mathrm{N}}$ for the Neoproterozoic mafic-ultramafic rocks in the Quruqtagh block, Tarim Craton. Values used in mixing calculations: granite (Cao et al., 2014), average ocean island basalt (OIB) (Li et al., 2015), the compositions of continental arc basalts (CAB) are from GEOROC (http://georoc.mpch-mainz.gwdg.de/georoc/).

the age progressions occur in different directions. For example, the mafic-ultramafic complexes that occur to the west and to the east of the Xingdi II mafic-ultramafic complex are all younger than this complex (Fig. 2a). As shown in Fig. 2a, the Xingdi I and II mafic-ultramafic complexes, which were emplaced up to 21-myr apart, occur within the same fault-bounded block. Their current distance is $\sim 10 \mathrm{~km}$. Their original distance should be similar to this value because there is no clear offset by post-magmatic faulting between them. The original 


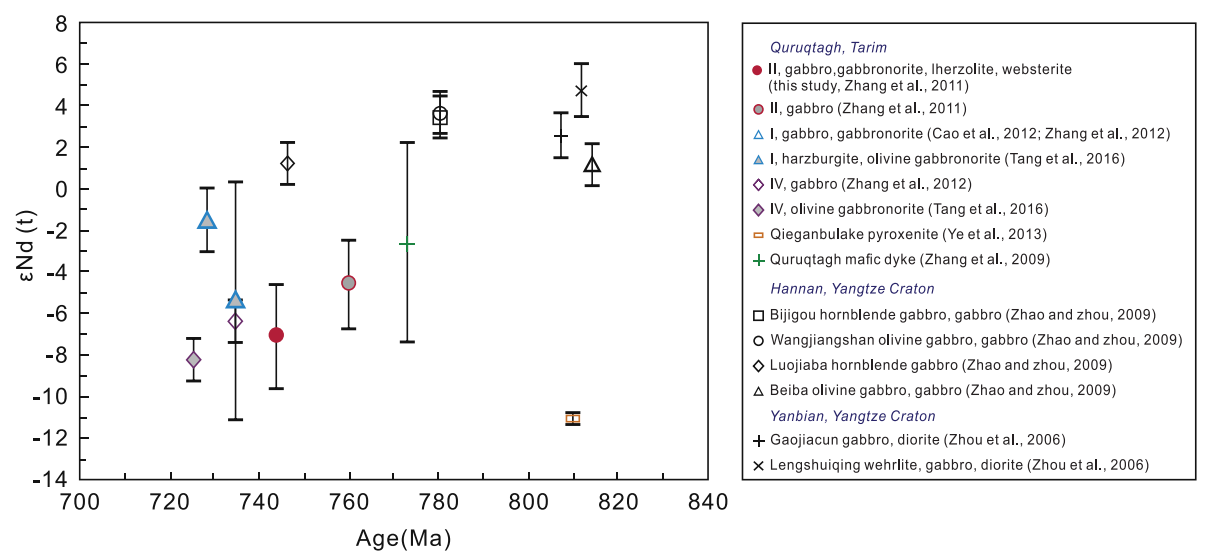

Fig. 10. Plot of $\varepsilon \mathrm{Nd}(\mathrm{t})$ versus ages for the Neoproterozoic mafic-ultramafic rocks from the Quruqtagh block, Tarim Craton, and the Hannan and Yanbian regions, Yangtze Craton.

distance between the Xingdi II and IV mafic-ultramafic complexes may have been affected by post-magmatic faulting. However, as indicated by only minor offset for the associated granite pluton in the north of the IV mafic-ultramafic complex, the total lateral movement of the NE-trending faults in the areas is $<1 \mathrm{~km}$. The lateral movement of the E-W trending faults is not known but likely not significant because the associated Neoproterozoic plutons show no sign of significant offset (Fig. 2a). In summary, the large age variation of the Neoproterozoic mafic-ultramafic complexes (730-820 Ma) in such a small area is not consistent with a mantle plume origin. On the other hand, repeated basaltic magmatism with a large hiatus in an area as small as a single intrusive complex is common for subduction-related magmatism such as the Duke Island mafic-ultramafic complex in southern Alaska (Thakurta et al., 2008).

Petrographic observations of the Xingdi II mafic-ultramafic complex show that some samples contain abundant magmatic hornblende or biotite (Fig. 3b, c). This indicates that there was some initial water in the parental magma, consistent with subduction-related magmas. In addition, the mafic-ultramafic intrusions and mafic dykes in this area are generally enriched in light-REE and depleted in $\mathrm{Nb}$, both features

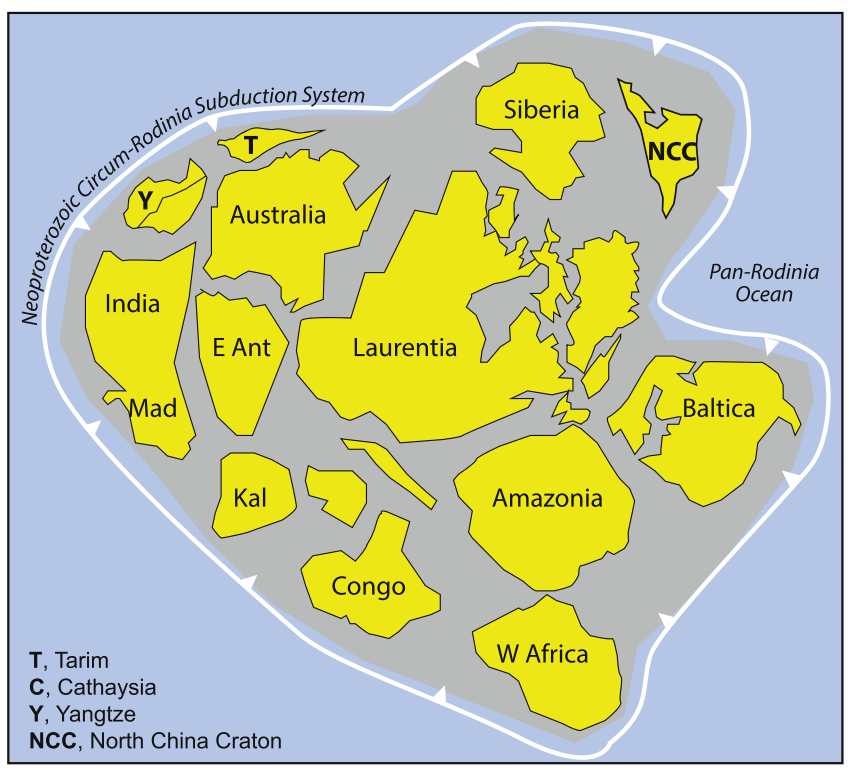

Fig. 11. The Neoproterozoic Circum-Rodinia Subduction System. (After Cawood et al., 2013; Tang et al., 2016). that are common for subduction-related magmas. Therefore, we believe that the Neoproterozoic mafic-ultramafic rocks in the Quruqtagh block of the Tarim Craton are the products of subduction-related magmatism instead of mantle plume activity.

Our model is consistent with geological records as well, such as the occurrences of the 700-750 Ma high-pressure/low-temperature blueschists (Liou et al., 1996; Nakajima et al., 1990; Yong et al., 2012; Zhu et al., 2011b) and the 790-830 Ma high-grade metamorphic rocks (Ge et al., 2013; He et al., 2014) in the region. The new lines of evidence described above support the notion that in the Neoproterozoic the northern rim of the Tarim Craton was an active continental margin belonging to the so-called Circum-Rodinia Subduction System proposed recently by some researchers (Fig. 11, Cawood et al., 2013; Tang et al., 2016).

\section{Conclusions}

Based on temporal-spatial distribution and geochemical characteristics, we find no evidence to support the hypothesis that the Neoproterozoic mafic-ultramafic rocks (760-820 Ma) in the northern rim of the Tarim Craton were related to two episodes of super plume activity. Our new data together with previous results indicate that the Neoproterozoic mafic-ultramafic complexes and mafic dykes in the Quruqtagh block of the Tarim Craton are petrologically and geochemically consistent with the products of subduction-related basaltic magmatism in a continental arc setting. Our findings support the notion that in the Neoproterozoic the northern rim of the Tarim Craton was an active continental margin, a part of the Circum-Rodinia Subduction System.

Supplementary data to this article can be found online at http://dx. doi.org/10.1016/j.lithos.2017.01.014.

\section{Acknowledgments}

This study was financially supported by the China Geological Survey Bureau (1212011140056). We thank Lianhui Dong, Xun Qu and Changzhi Wu for their assistance in field work, and Hong Zhang, Mengning Dai, Zhibin Xiao, Libing Gu, Bin Yang, and Wenping Zhu for their assistance in isotopic and chemical analyses. Constructive comments from two reviewers and guidance from the editor are greatly appreciated. This manuscript was written during the first author's visit to Indiana University, supported by the China Scholarship Council (201506010049).

\section{References}

Blichert-Toft, J., Albarède, F., 1997. The Lu-Hf isotope geochemistry of chondrites and the evolution of the mantle-crust system. Earth and Planetary Science Letters 148, 243-258. 
Branney, M.J., Bonnichsen, B., Andrews, G.D.M., Ellis, B., Barry, T.L., McCurry, M., 2008. 'Snake River (SR)-type' volcanism at the Yellowstone hotspot track: distinctive products from unusual, high-temperature silica super-eruptions. Bulletin of Volcanology 70, 293-314.

Cao, X.F., Gao, X., Lü, X.B., Qin, Q., Liu, S.T., Chen, C., Guo, R.Q., Zhang, B., Hu, Q.T., 2012. $\mathrm{Sm}-\mathrm{Nd}$ geochronology and geochemistry of a Neoproterozoic gabbro in Kuluktage block, north-western China. International Geology Review 54, 861-875.

Cao, X.F., Lü, X.B., Yuan, Q., Wang, X.D., Liu, H., Shen, W., 2014. Neoproterozoic granitic activities in the Xingdi plutons at the Kuluketage block, NW China: evidence from zircon $\mathrm{U}-\mathrm{Pb}$ dating, geochemical and $\mathrm{Sr}-\mathrm{Nd}-\mathrm{Hf}$ isotopic analyses. Journal of Asian Earth Sciences 96, 93-107.

Cawood, P.A., Wang, Y., Xu, Y., Zhao, G., 2013. Locating South China in Rodinia and Gondwana: a fragment of greater India lithosphere? Geology 41, 903-875.

Chu, N.C., Taylor, R.N., Chavagnac, V., Nesbitt, R.W., Boella, R.M., Milton, J.A., Germain, C.R., Bayon, G., Burton, K., 2002. Hf isotope ratio analysis using multi-collector inductively coupled plasma mass spectrometry: an evaluation of isobaric interference corrections. Journal of Analytical Atomic Spectrometry 17, 1567-1574.

Compston, W., Williams, I.S., Kirschvink, J.L., Zhang, Z., Ma, G., 1992. Zircon U-Pb ages for the Early Cambrian time-scale. Journal of the Geological Society of London 149, 171-184

DeBievre, P., Taylor, P.D.P., 1993. Table of the isotopic composition of the elements. International Journal of Mass Spectrometry and Ion Processes 123, 149

Dong, Y.P., Liu, X.M., Santosh, M., Chen, Q., Zhang, X.N., Li, W., He, D.F., Zhang, G.W., 2012. Neoproterozoic accretionary tectonics along the northwestern margin of the Yangtze Block, China: constraints from zircon U-Pb geochronology and geochemistry. Precambrian Research 196-197, 247-274

Elhlou, S., Belousova, E., Griffin, W.L., Pearson, N.J., O'Reilly, S.Y., 2006. Trace element and isotopic composition of GJ red zircon standard by laser ablation. Geochimica et Cosmochimica Acta 70 (Suppl. 1), A158.

Gao, Z.J., Chen, J.B., Lu, S.N., Peng, C.W., Qin, Z.Y., 1993. The Precambrian geology in northern Xinjiang. Precambrian Geology No. 6. Geological Publishing House, Beijing (in Chinese).

Ge, R.F., Zhu, W.B., Wu, H.L., Zheng, B.H., He, J.W., 2013. Timing and mechanisms of multiple episodes of migmatization in the Korla Complex, northern Tarim Craton, NW China: constraints from zircon U-Pb-Lu-Hf isotopes and implications for crustal growth. Precambrian Research 231, 136-156.

Ge, R., Zhu, W., Wilde, S.A., He, J., Cui, X., Wang, X., Zheng, B., 2014. Neoproterozoic to Paleozoic long-lived accretionary orogeny in the northern Tarim Craton. Tectonics 33, 302-329.

Guo, Z.J., Yin, A., Robinson, A., Jia, C.Z., 2005. Geochronology and geochemistry of deepdrill-core samples from the basement of the central Tarim basin. Journal of Asian Earth Sciences 25, 45-56.

He, J.W., Zhu, W.B., Ge, R.F., 2014. New age constraints on Neoproterozoic diamicites in Kuruktage, NW China and Precambrian crustal evolution of the Tarim Craton. Precambrian Research 241, 44-60.

Jiang, C.Y., Lu, D.R., Bai, K.Y., Zhang, P.B., Ye, S.F., Feng, J.X., Chen, W.G., 2005. Metasomatism products of continental lithosphere mantle-roseite deposits, Qieganbulake. Acta Petrologica Sinica 23, 35-56 (In Chinese with English abstract).

Li, H.Q., Xie, C.F., Chang, H.L., Cai, H., Zhu, J.P., Zhou, S., 1998. Study on the Metallogenetic Chronology of Nonferrous and Precious Metallic Ore Deposits in North Xinjiang, China. Geological Publishing House, Beijing, pp. 1-250 (In Chinese).

Li, Z.X., Li, X.H., Kinny, P.D., Wang, J., 1999. The breakup of Rodinia: did it start with a mantle plume beneath South China? Earth and Planetary Science Letters 173, 171-181.

Li, X.H., Zhu, W.G., Zhong, H., Wang, X.C., He, D.F., Bai, Z.J., Liu, F., 2010. The Tongde picritic dikes in the Western Yangtze Block: evidence for ca. 800 Ma mantle plume magmatism in South China during the breakup of Rodinia. Journal of Geology 118, $509-522$

Li, C.F., Li, X.H., Li, Q.L., Guo, J.H., Li, X.H., Yang, Y.H., 2012. Rapid and precise determination of $\mathrm{Sr}$ and $\mathrm{Nd}$ isotopic ratios in geological samples from the same filament loading by thermal ionization mass spectrometry employing a single-step separation scheme. Analitica Chemica Acta 727, 54-60.

Li, C., Arndt, N.T., Tang, Q., Ripley, E.M., 2015. Trace element indiscrimination diagrams. Lithos 232, 76-83.

Liou, J.G., Graham, S.A., Maruyama, S., Zhang, R.Y., 1996. Characteristics and tectonic significance of the Late Proterozoic Aksu blueschists and diabasic dikes, northwest Xinjiang, China. International Geology Review 38, 228-244.

Long, X.P., Yuan, C., Sun, M., Zhao, G.C., Xiao, W.J., Wang, Y.J., Yang, Y.H., Hu, A.Q., 2010. Archean crustal evolution of the northern Tarim Craton, NW China: zircon U-Pb and Hf isotopic constraints. Precambrian Research 180, 272-284

Long, X.P., Yuan, C., Sun, M., Kröner, A., Zhao, G.C., Wilde, S., Hu, A.Q., 2011a. Reworking of the Tarim Craton by underplating of mantle plume-derived magmas: evidence from Neoproterozoic granitoids in the Kuluketage area, NW China. Precambrian Research $187,1-14$.

Long, X.P., Yuan, C., Sun, M., Xiao, W.J., Zhao, G.C., Zhou, K.F., Wang, Y.J., Hu, A.Q., 2011b. The discovery of the oldest rocks in the Kuluketage area and its geological implications. Science China Earth Sciences 54, 342-348.

Lu, S.N., 1992. The Proterozoic tectonic evolution of Kuruketage, Xinjiang. Journal of Tianjin Geology and Mineral Resources 26-27, 279-292 (in Chinese with English abstract).

Lu, S.N., Li, H.K., Zhang, C.L., Niu, G.H., 2008. Geological and geochronological evidence for the Precambrian evolution of the Tarim Craton and surrounding continental fragments. Precambrian Research 160, 94-107.

Ludwig, K.R., 2003. Squid 1.02: A user manual vol. 12. Berkeley Geochronological Center Special Publication (19 pp.

Morgan, W.J., 1971. Convection plumes in the lower mantle. Nature 230, 42-43.
Munteanu, M., Wilson, A.H., Yao, Y., Chunnett, G., Luo, Y., 2010. Sequence of magma emplacement and sulphide saturation in the Gaojiacun-Lengshuiqing intrusive complex (SW China). Mineralium Deposita 45, 517-529.

Nakajima, T., Maruyama, S., Uchiumi, S., Liou, J.G., Wang, X., Xiao, X., Graham, S.A., 1990 Evidence for late Proterozoic subduction from700-Myr-old blueschists in China. Nature 346, 263-265.

Raczek, I., Jochum, K.P., Hofmann, A.W., 2003. Neodymium and strontium isotope data for USGS reference materials BCR-1, BCR-2, BHVO-1, BHVO-2, AGV-1, AGV-2, GSP-1 GSP-2 and eight MPI-DING reference glasses. The Journal of Geostandards and Geoanalysis 27, 173-179.

Rudnick, R.L., Gao, S., 2014. Composition of the continental crust. In: Rudnick, R.L. (Ed.) Treatise on Geochemistry. Elsevier, Amsterdam, pp. 1-51.

Shu, L.S., Deng, X.L., Zhu, W.B., Ma, D.S., Xiao, W.J., 2011. Precambrian tectonic evolution of the Tarim Block, NW China: new geochronological insights from the Quruqtagh domain. Journal of Asian Earth Sciences 42, 774-790.

Söderlund, U., Patchett, P.J., Vervoort, J.D., Isachsen, C.E., 2004. The ${ }^{176} \mathrm{Lu}$ decay constant determined by Lu-Hf and U-Pb isotope systematic of Precambrian mafic intrusions. Earth and Planetary Science Letters 219, 311-324.

Sun, S.S., McDonough, W.F., 1989. Chemical and isotopic systematics in ocean basalt: implication for mantle composition and processes. In: Saunders, A.D., Norry, M.J. (Eds.), magmatism in the ocean basins. Geological Society, London, Special Publications 42, 313-345.

Tanaka, T., Togashi, S., Kamioka, H., Amakawa, H., Kagami, H., Hamamoto, T., Yuhara, M. Orihashi, Y., Yoneda, S., Shimizu, H., Kunimaru, T., Takahashi, K., Yanagi, T., Nakano, T., Fujimaki, H., Shinjo, R., Asahara, Y., Tanimizu, M., Dragusanu, C., 2000. Jindi-1: neodymium isotopic reference in consistency with Lajolla neodymium. Chemical Geology 168, 279-281.

Tang, Q.Y., Zhang, Z.W., Li, C., Wang, Y.L., Ripley, E.M., 2016. Neoproterozoic subductionrelated basaltic magmatism in the northern margin of the Tarim Craton: implications for Rodinia reconstruction. Precambrian Research 286, 370-378.

Thakurta, J., Ripley, E.M., Li, C., 2008. Geochemical constraints on the origin of sulfide mineralization in the Duke Island Complex, southeastern Alaska. Geochemistry, Geophysics, Geosystems 9. http://dx.doi.org/10.1029/2008GC001982.

Tilling R.I. Heliker, C. Swanson, D.A., 2010. Origin of the Hawaiian islands. In: eruptions of Hawaiian volcanoes-past, present, and future. U.S. Geological Survey. General Information Product 117, 4-10.

Wang, X.L., Zhou, J.C., Qiu, J.S., Zhang, W.L., Liu, X.M., Zhang, G.L., 2006. LA-ICP-MS U-Pb zircon geochronology of the Neoproterozoic igneous rocks from Northern Guangxi Province, South China: implications for the tectonic evolution. Precambrian Research $145,111-130$

XBGMR (Xinjiang Bureau of Geology and Mineral Resources), 1993. Regional Geology of Xinjiang Uygur Autonomy Region. Geological Publishing House, Beijing (in Chinese).

XBGMR-3 (No. 3 Geology Team of Xinjiang Bureau of Geology and Mineral Resources), 2003a. Geological Map of Xingdi II Mafic-Ultramafic Complex From Yuli County, Xinjiang Province.

Xu, B., Jian, P., Zheng, H.F., Zou, H.B., Zhang, L.F., Liu, D.Y., 2005. U-Pb geochronology and geochemistry of Neoproterozoic volcanic rocks in the Tarim Block of northwest China: implications for the breakup of Rodinia supercontinent and Neoproterozoic glaciations. Precambrian Research 136, 107-123.

Yao, J., Shu, L., Santosh, M., Zhao, G., 2014. Neoproterozoic arc-related mafic-ultramafic rocks and syn-collision granite from the western segment of the Jiangnan Orogen, South China: constraints on the Neoproterozoic assembly of the Yangtze and Cathaysia Blocks. Precambrian Research 243, 39-62.

Ye, H.M., Li, X.H., Lan, Z.W., 2013. Geochemical and Sr-Nd-Hf-O-C isotopic constraints on the origin of the Neoproterozoic Qieganbulake ultramafic-carbonatite complex from the Tarim Block, Northwest China. Lithos 182-183, 150-164.

Yong, W.J., Zhang, L.F., Hall, C.M., Mukasa, S.B., Essene, E.J., 2012. The ${ }^{40} \mathrm{Ar} /{ }^{39} \mathrm{Ar}$ and Rb-Sr chronology of the Precambrian Aksu blueschists in western China. Journal of Asian Earth Sciences 63, 197-205.

Yuan, Y.X., Pan, C.X., Qian, Y.Z., 2002. Cu-Ni-bearing property evolution of Xingdi complex no. II in Kuruketage, Xinjiang. Xinjiang Geology 20, 49-52 (in Chinese with English abstract).

Yuan, H.L., Gao, S., Dai, M.N., Zong, C.L., Günther, D., Fontaine, G.H., Liu, X.M., Diwu, C.R 2008. Simultaneous determinations of $\mathrm{U}-\mathrm{Pb}$ age, $\mathrm{Hf}$ isotopes and trace element compositions of zircon by excimer laser-ablation quadrupole and multiple collector ICP-MS. Chemical Geology 247, 100-118.

Zhang, C.L., Li, X.H., Li, Z.X., Lu, S.N., Ye, H.M., Li, H.M., 2007. Neoproterozoic maficultramafic-carbonatite complex and granitoids in Quruqtagh of northeastern Tarim Block, western China: geochronology, geochemistry and tectonic implications. Precambrian Research 152, 149-169.

Zhang, C.L., Li, Z.X., Li, X.H., Ye, H.M., 2009. Neoproterozoic mafic dyke swarm in north margin of the Tarim, NW China: age, geochemistry, petrogenesis and tectonic implications. Journal of Asian Earth Sciences 35, 167-179.

Zhang, M., Kamo, S.L., Li, C., Hu, P., Ripley, E.M., 2010. Precise U-Pb zircon-baddeleyite age of the Jinchuan sulfide ore-bearing ultramafic intrusion, western China. Mineralium Deposita 45, 3-9.

Zhang, C.L., Yang, D.S., Wang, H.Y., Takahashi, Y., Ye, H.M., 2011. Neoproterozoic ultramafic-mafic layered intrusion in Quruqtagh of northeastern Tarim Block, NW China: two phases of mafic igneous activity of different mantle sources. Gondwana Research 19, 177-190.

Zhang, C.L., Zou, H.B., Wang, H.Y., Li, H.K., Ye, H.M., 2012. Multiple phases of the Neoproterozoic igneous activity in Quruqtagh of the northeastern Tarim Block, NW China: interaction between plate subduction and mantle plume? Precambrian Research 222-223, 488-502.

Zhao, G., Cawood, P.A., 2012. Precambrian geology of China. Precambrian Research 222-223, 13-54. 
Zhao, J.H., Zhou, M.F., 2009. Secular evolution of the Neoproterozoic lithospheric mantle underneath the northern margin of the Yangtze Block, South China. Lithos 107, $152-168$.

Zhou, M.F., Ma, Y.X., Yan, D.P., Xia, X.P., Zhao, J.H., Sun, M., 2006. The Yanbian Terrane (Southern Sichuan Province, SW China): a Neoproterozoic arc assemblage in the western margin of the Yangtze Block. Precambrian Research 144, 19-38.

Zhu, W.G., Zhong, H., Li, X.H., Deng, H.L., He, D.F., Wu, K.W., Bai, Z.J., 2008. SHRIMP zircon $\mathrm{U}-\mathrm{Pb}$ geochronology, elemental, and Nd isotopic geochemistry of the Neoproterozoic mafic dykes in the Yanbian area, SW China. Precambrian Research 164, 66-85.

Zhu, W.B., Zheng, B.H., Shu, L.S., Ma, D.S., Wan, J.L., Zheng, D.W., Zhang, Z.Y., Zhu, X.Q. 2011a. Geochemistry and SHRIMP U-Pb zircon geochronology of the Korla mafic dykes: constrains on the Neoproterozoic continental breakup in the Tarim Block, Northwest China. Journal of Asian Earth Sciences 42, 791-804.

Zhu, W.B., Zheng, B.H., Shu, L.S., Ma, D.S., Wu, H.L., Li, Y.X., Huang, W.T., Yu, J.J., 2011b. Neoproterozoic tectonic evolution of the Precambrian Aksu blue schist terrace, northwestern Tarim, China: insights from LA-ICP-MS zircon U-Pb ages and geochemical data. Precambrian Research 185, 215-230.

Zindler, A., Hart, S.R., 1986. Chemical geodynamics. Annual Review of Earth and Planetary Sciences $14,493-571$ 